\title{
Immune response and growth performance of crayfish Cherax quadricarinatus fed with synbiotic supplemented diet
}

\section{Performa respons imun dan pertumbuhan lobster air tawar Cherax quadricarinatus yang diberi pakan mengandung sinbiotik}

\author{
Amrullah $^{1 *}$, Wahidah ${ }^{1}$ \\ ${ }^{1}$ Department of Aquaculture, Pangkep State Polytechnic of Agriculture \\ Jl. Poros Makassar-Pare-Pare, KM. 82 Mandalle, Pangkajene Kepulauan, South Sulawesi \\ *Corresponding author : ulla_285@yahoo.com
}

(Received May 25, 2018; Accepted October 23, 2018)

\begin{abstract}
This study aimed to investigate the effectiveness of synbiotic (prebiotic alginate and probiotic bacteria Micrococcus spp) on the immune responses, growth performance, and bacterial resistance of freshwater crayfish. The experimental diets were formulated in three levels of synbiotic: the probiotic bacteria Micrococcus $\mathrm{spp}+100 \mathrm{mg} / \mathrm{L}$ alginate (Syn100), Micrococcus $\mathrm{spp}+200 \mathrm{mg} / \mathrm{L}$ alginate (Syn200), Micrococcus $\mathrm{spp}+300 \mathrm{mg} / \mathrm{L}$ alginate (Syn300), each level was mixed with tested feed. The basal diet (without synbiotics) served as the control diet. During 40 days of rearing, immune responses observations were conducted every 10 days, while the crayfish weight was recorded on day 40. Furthermore, the challenge test was performed against the pathogenic bacteria of Aeromonas hydrophila and reared for a week. The result showed that synbiotics treatment of Syn300 and Syn200 could improve the immune response and increased the growth rate $(\mathrm{P}<0.05)$. Both were also higher than that of the Syn 100 treatment, while the lowest was the control. The highest resistance to A. hydrophila pathogenic bacteria by demonstrating a higher survival rate was Syn300 and followed by Syn200 (70.00 $\pm 0 \%$ and $73.33 \pm 5.77 \%$, respectively), compared to Syn100 $(56.67 \pm 3.33 \%)$ and the control $(33.33 \pm 3.33 \%)$. The synbiotic Micrococcus spp. combined with alginate potentially induced immune responses, increased growth performance, and improved bacterial pathogens resistance, making it an ideal synbiotic to be developed.
\end{abstract}

Keywords: synbiotic, prebiotic, probiotic, Sargassum sp., alginate, brown algae

\begin{abstract}
ABSTRAK
Penelitian ini bertujuan untuk menguji efektivitas penggunaan sinbiotik (prebiotik alginat dan probiotik Micrococcus spp) terhadap respons imun, performa pertumbuhan dan resistansi lobster air tawar terhadap bakteri patogen. Tiga perlakuan sinbiotik, yaitu: Micrococcus spp+100 mg/L alginat (Syn100), Micrococcus spp+200 mg/L alginat (Syn200), Micrococcus spp+300 mg/L alginat (Syn300), masing-masing dicampurkan ke dalam pakan dan diberikan ke lobster. Pakan tanpa campuran prebiotik digunakan sebagai pakan kontrol. Selama 40 hari pemeliharaan, pengamatan respons imun dilakukan setiap 10 hari, dan pada hari ke-40 pemeliharaan dilakukan pengukuran bobot lobster. Selanjutnya, lobster diuji tantang dengan bakteri A. hydrophila dan dipelihara kembali selama satu minggu. Hasil penelitian menunjukkan bahwa pemberian pakan yang mengandung sinbiotik Syn300 dan Syn200 dapat meningkatkan respons imun dan pertumbuhan $(\mathrm{P}<0,05)$ lebih tinggi dibandingkan dengan perlakuan Syn100, sementara bobot tubuh terendah didapat pada perlakuan kontrol. Resistensi lobster tertinggi terhadap bakteri A. hydrophila yang ditunjukkan dengan sintasan tertinggi didapatkan pada perlakuan Syn300 $(70,00 \pm 0,00 \%)$ dan Syn200 (73,33 $\pm 5,77 \%)$ dibandingkan dengan perlakuan Syn100 $(56,67 \pm 3,33 \%)$ dan kontrol $(33,33 \pm 3,33 \%)$. Penelitian ini membuktikan bahwa sinbiotik Micrococcus spp. yang dikombinasikan dengan alginat dapat menginduksi respons imun, meningkatkan performa pertumbuhan, dan resistansi terhadap patogen sehingga merupakan sinbiotik yang ideal untuk dikembangkan.
\end{abstract}

Kata kunci: sinbiotik, prebiotik, probiotik, Sargassum sp., alginat, alga coklat 


\section{INTRODUCTION}

The disease is a major threat to aquaculture production. Nonetheless, it mostly deals with antibiotic for controlling disease outbreak. It leads to resistance of pathogenic bacteria in various species and potentially leads to the environmental destruction. Therefore, preventive action through improvement of the fish or prawn's immunity is highly crucial. Various studies related to the application of vaccines have been documented, including whole cell vaccines and extracellular products (Pasnik et al., 2005), extracellular proteins (Song et al., 2013), and the $89 \mathrm{kDa}$ protein extracellular vaccine (Amrullah et al., 2014a; 2014b). Studies about immunostimulants, among them, referring to LPS characterization (Cai et al., 2013), flagellin from Marinobacter algicola and Vibrio vulnificus (Montero et al., 2014), and nutritional impact on fish mucosa (Caipang \& Lazado, 2015) have been reported.

In addition, vaccines, immunostimulants, and probiotics have played various important roles in aquaculture and resulted numerous developments (Sharifuzzaman et al., 2014; Park et al., 2016; Speranza et al., 2017), leading to the development of "prebiotics" such as mannan oligosaccharides (MOS), fructooligosaccharides (FOS), inulin and vitamin C (Torrecillas et al., 2007; Zhou et al., 2010; Ibrahem et al., 2010; Munir et al., 2016), probiotics (Bacillus coagulans) and prebiotics B-GOS galactooligosaccharides) and fat intake in modulating the immune response (Liu et al., 2017). The most current developments are nutritional supplements, combinations of a probiotic and a prebiotic which are called synbiotics. Synbiotics have demonstrated more effective and long-lasting effects on growth and immunological responses (Van Doan et al., 2016; Wang et al., 2017; Safari \& Paolucci, 2017; Hindu et al., 2018). Similarly, Sewaka et al. (2019) found that the synbiotic application on the juvenile of red tilapia (Oreochromis spp) caused the intestines villus becoming high and wide. This leads to the expansion of food absorption area and feeds efficiency.

The brown algae (Phaeophyceae) contain polysaccharides such as laminaran, fucoidan, and alginate (Blanco-Pascual et al., 2014) in addition to mannitol and traces of cellulose (Chang et al., 2010; Seon et al., 2014). Alginate is a complex combination of oligo-polymer, mainly consisting of polymannuronic and polyglucuronic acids (Blanco-Pascual et al., 2014). Alginate is found in the cell wall where the main supportive material located, comprising up to $40 \%$ of the algae's dry weight (Draget et al., 2005; Jung et al., 2013; Seon et al., 2014). The application of alginate from brown algae in human increase gastroprotective and reduce the lesions occurrence in the human stomach (Ammar et al., 2018; Qin, 2018) and as prebiotics, antimicrobials, immunomodulation (Dierick et al., 2010). Applications on tilapia (Van Doan et al., 2017) and sea cucumbers (Wang et al., 2017) using alginate from brown algae have been performed and showed positive response in growth performance and immune system.

The freshwater crayfish, Cherax quadricarinatus, is a type of crayfish which commonly cultivated in Indonesia with a lot of economic potentials. However, its slow growth rate and susceptibility to bacterial diseases, especially Aeromonas hydrophila, are crucial issues in intensive lobster cultivation systems. In addition, a high density and limited area which cause stress in the animals, encourage the development of diseases and causing slow growth and might end in mass mortality. In order to overcome those issues, synbiotics is a plausible alternative way required for biological control (Wang et al., 2017).

The bacteria Micrococcus spp. (coded BTL) that isolated from the intestines of $C$. quadricarinatus grow well in media containing alginate in vitro (Amrullah et al., 2014c); therefore, the present study aimed to investigate the effectiveness of the synbiotic using the combination of the Micrococcus spp as potential probiotics and the prebiotic alginate extracted from brown algae Sargassum crassifolium. In addition, some parameters measured such as growth performance, immune response, and resistance of freshwater crayfish to pathogenic bacteria. Furthermore, the health status and disease of $C$. quadricarinatus were also observed using immune response and A. hydrophila resistance towards synbiotic supplementation.

\section{MATERIALS AND METHODS}

\section{Experimental crayfish}

The freshwater crayfish C. quadricarinatus, in similar age groups, were obtained from a number of crayfish cultivation centers in South Sulawesi, Indonesia. The average body weight of the crayfish used for the experiment was $9.45 \pm 47 \mathrm{~g}$.

\section{Prebiotics bacteria and prebiotic preparation}

Prebiotics was extracted from alginate of brown algae $S$. crassifolium. Probiotic bacteria 
Micrococcus spp. were isolated from the intestines of freshwater crayfish C. quadricarinatus, the best probiotic bacteria chosen based on in vitro testing (Amrullah et al., 2014c). The challenge test was done with a virulent strain of Aeromonas hydrophila bacteria. The crayfish was acclimatized under aerated conditions for a period of 14 days at $28^{\circ} \mathrm{C}$. The lobsters were fed a commercial lobster feed using ad libitum feeding method twice a day during the acclimatization period.

\section{Alginate extraction}

The alginate extraction of $S$. crassifolium was performed according to Murdinah et al. (2005). Dried S. crassifolium was immersed in $1 \% \mathrm{HCl}$ $1: 30 \mathrm{~b} / \mathrm{v}$ for 1 hour. Chemical extraction was conducted with $2 \% \mathrm{Na}_{2} \mathrm{CO}_{3}(1: 30)$ at $60-70^{\circ} \mathrm{C}$ for 60 minutes. The sample was grounded and re-extracted at $60-70^{\circ} \mathrm{C}$ for $60 \mathrm{~min}$. Next, the extracts were blended with $\mathrm{NaOCl}(4 \%$ of filtrate volume) for $30 \mathrm{~min}$. Alginic acid was obtained with the addition of $10 \% \mathrm{HCl}$ at $\mathrm{pH}$ between 2.8 and 3.2. In addition, alginate acid was washed to neutral. A $10 \% \mathrm{NaOH}$ was used for Na-alginate conversion with $\mathrm{pH} 7-8$ and continued with $\mathrm{Na}-$ alginate separation in IPA $(1: 2 \mathrm{v} / \mathrm{v})$, stirred for 30 minutes. Moreover, oven drying at $50^{\circ} \mathrm{C}$ for 12 hours was applied. The sample was grounded to powder to obtain alginate flour.

\section{Experimental diet preparation}

The basal diet contained $30 \%$ protein, $5 \%$ fat, $4 \%$ fiber, and $12 \%$ moisture. Three different experimental feeds were used by adding alginate 100,200 , and $300 \mathrm{mg} / \mathrm{L}$ for each. One control feed group was provided for the experimental animal (without any prebiotic). The resulting dough was cold-extruded through a palletiser with an appropriate size. The pellets were air-dried and stored at room temperature in air-tight containers. The feed was then sprayed with Micrococcus spp. The experimental feed was stored in sealed plastic bags at $4^{\circ} \mathrm{C}$ before used for the further experiment.

\section{Experimental design and culture system}

A completely randomized design was applied for a laboratory experiment. Three different experimental feeds were used; probiotic bacteria Micrococcus spp $+100 \mathrm{mg} / \mathrm{L}$ alginate (Syn100), Micrococcus spp $+200 \mathrm{mg} / \mathrm{L}$ alginate (Syn200), and Micrococcus spp $+300 \mathrm{mg} / \mathrm{L}$ alginate (Syn300) which had three replication for each. While four different rearing periods of synbiotic treatment were used, 10 days, 20 days, 30 days, and 40 days. The basal diet (without synbiotics) was served as the control diet. After acclimation, the experimental animals were reared in fiber glass tanks (40 L capacity) at a density of 15 crayfish per aquarium. Feeding was conducted twice a day using ad libitum method. The crayfish were reared for 40 days and observations of immune responses were made every 10 days and they were weighed on day 40 .

\section{Challenge test}

The freshwater crayfish were reared in fiber glass tanks ( 40 L capacity) with a density of 10 freshwater crayfish/tank triplicate and fed twice a day at a feeding rate of $5 \%$ of body weight. After 40 days of the feeding trial, the crayfish were challenged with $10^{6} \mathrm{CFU} / \mathrm{mL}$ the bacteria $A$. hydrophila. The survival rate of the lobsters was observed on the $7^{\text {th }}$ day post-challenge test.

\section{Statistical analysis}

Data survival rate, body weight, total hemocyte count, differential hemocyte count, and phagocytic activity were statistically analyzed using one-way ANOVA with SPSS 26.0 (SPSS Inc. IL) program. Significant different $(\mathrm{P}<0.05)$ was further tested with the Duncan test.

\section{RESULTS AND DISCUSSION}

\section{Results}

\section{Total hemocyte count}

The prebiotics alginate mixed with the probiotic bacteria Micrococcus spp as a synbiotic (Figure 1), could increase the total hemocyte count which was demonstrated by the distribution of total hemocyte in each treatment which increased until day 40 . The average total hemocyte count in treatment was between 8.5-3.9 $\left(\times 10^{6} \mathrm{cells} / \mathrm{mL}\right)$, while control treatment was $3.17-2.97 \times 10^{6} \mathrm{cells} / \mathrm{mL}$ ).

The statistical analysis results showed there was a significant difference in level and treatment duration of symbiotic on total hemocyte count. Nonetheless, there was no interaction between the synbiotic concentration and treatment duration $(\mathrm{P}<0.05)$. The main effect of synbiotics concentration on average total hemocyte response for 40 days regardless of the effect of treatment duration indicated that the treatment of $200 \mathrm{mg} / \mathrm{L} \mathrm{(5.94)} \mathrm{and} 300 \mathrm{mg} / \mathrm{L}$ (5.78) were significantly different $(\mathrm{P}<0.05)$ and higher than the the treatment of $100 \mathrm{mg} / \mathrm{L}$ (5.01) and control (3.08). Furthermore, the main effect 


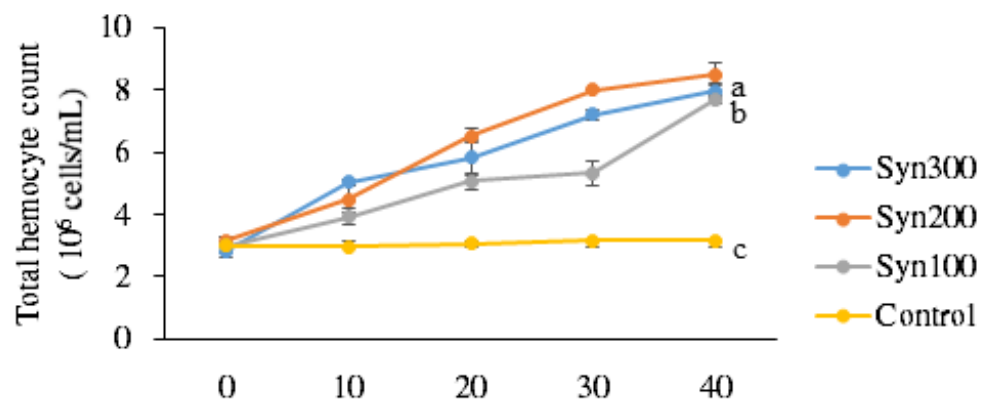

Day after synbiotic administration

Figure 1. The average of total hemocyte count of crayfish Cherax quadricarinatus after being fed synbiotic-enriched feed with different level of synbiotic and duration of treatment (mean \pm SD). Different superscript letters indicate significant differences among treatments $(\mathrm{P}<0.05)$.

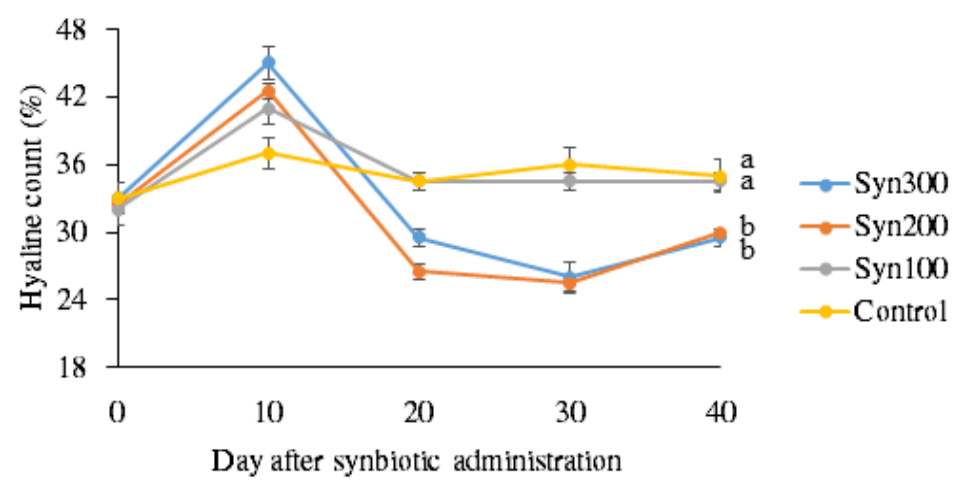

Figure 2. Average hyaline count of crayfish Cherax quadricarinatus after being fed synbiotic-enriched feed with different level of synbiotic and duration of treatment $(m e a n \pm S D)$. Different superscript letter indicate significant differences between treatments $(\mathrm{P}<0.05)$.

Table 1. Average semi granulocyte count of crayfish Cerax quadricarinatus after being fed synbiotic-enriched feed with different level of synbiotic and duration of treatment.

\begin{tabular}{|c|c|c|c|c|c|}
\hline \multirow{2}{*}{$\begin{array}{l}\text { Different level of synbiotic } \\
\qquad(\mathrm{mg} / \mathrm{L})\end{array}$} & \multirow{2}{*}{$\begin{array}{l}\text { Duration of treatment } \\
\text { (day) }\end{array}$} & \multicolumn{4}{|c|}{$\begin{array}{c}\text { Average semi granulocyte count of crayfish Cerax } \\
\text { quadricarinatus }(\%)\end{array}$} \\
\hline & & I & II & III & IV \\
\hline Syn200 & day-10 & 40.00 & & & \\
\hline Syn300 & day-10 & 39.50 & 39.50 & & \\
\hline Syn300 & day-0 & 37.00 & 37.00 & & \\
\hline Syn200 & day-0 & 36.50 & 36.50 & & \\
\hline Syn100 & day- 0 & 36.50 & 36.50 & & \\
\hline Control & day-0 & 36.50 & 36.50 & & \\
\hline Control & day-40 & 35.50 & 35.50 & & \\
\hline Syn100 & day-10 & & 34.50 & & \\
\hline Control & day-10 & & 34.50 & & \\
\hline Syn100 & day-20 & & 34.00 & 34.00 & \\
\hline Syn100 & day-40 & & 34.00 & 34.00 & \\
\hline Syn300 & day-30 & & 33.00 & 33.00 & \\
\hline Control & day-30 & & 33.00 & 33.00 & \\
\hline Control & day-20 & & 32.00 & 32.00 & \\
\hline Syn100 & day-30 & & 31.00 & 31.00 & \\
\hline Syn200 & day-20 & & 30.00 & 30.00 & \\
\hline Syn200 & day-30 & & & 29.00 & 29.00 \\
\hline Syn300 & day-40 & & & 27.00 & 27.00 \\
\hline Syn300 & day-20 & & & 24.50 & 24.50 \\
\hline Syn200 & day-40 & & & & 22.50 \\
\hline
\end{tabular}

Different column indicate significant differences among treatments $(\mathrm{P}<0.05)$ 
Table 2. Average granulocyte count of crayfish Cherax quadricarinatus after being fed synbiotic-enriched feed with different level of synbiotic and duration of treatment.

\begin{tabular}{|c|c|c|c|c|}
\hline \multirow{2}{*}{$\begin{array}{l}\text { Different level of synbiotic } \\
\qquad(\mathrm{mg} / \mathrm{L})\end{array}$} & \multirow{2}{*}{$\begin{array}{l}\text { Duration of treatment } \\
\text { (day) }\end{array}$} & \multicolumn{3}{|c|}{$\begin{array}{c}\text { Average granulocyte count of crayfish Cherax } \\
\text { quadricarinatus }(\%)\end{array}$} \\
\hline & & I & II & III \\
\hline Syn200 & day-40 & 47.50 & & \\
\hline Syn300 & day-20 & 46.00 & & \\
\hline Control & day-30 & 45.50 & & \\
\hline Syn300 & day-40 & 43.50 & & \\
\hline Syn200 & day-20 & 43.50 & & \\
\hline Syn100 & day-30 & 41.00 & & \\
\hline Control & day-20 & & 33.50 & \\
\hline Syn100 & day-0 & & 31.50 & \\
\hline Syn100 & day-20 & & 31.50 & \\
\hline Syn100 & day-40 & & 31.50 & \\
\hline Syn300 & day-30 & & 31.00 & \\
\hline Syn200 & day-0 & & 31.00 & \\
\hline Control & day-0 & & 30.50 & \\
\hline Control & day-40 & & 30.50 & \\
\hline Syn300 & day-0 & & 29.50 & \\
\hline Syn200 & day-30 & & 29.50 & \\
\hline Control & day-10 & & 28.50 & \\
\hline Syn100 & day-10 & & 27.50 & \\
\hline Syn200 & day-10 & & & 18.50 \\
\hline Syn300 & day-10 & & & 15.50 \\
\hline
\end{tabular}

Different colom indicate significant differences among treatments $(\mathrm{P}<0.05)$.

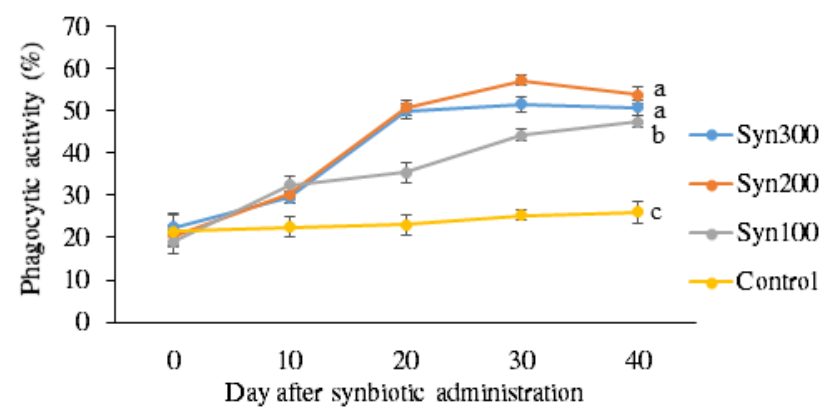

Figure 3. Average phagocytic activity of crayfish Cherax quadricarinatus after being fed synbiotic-enriched feed with different level of synbiotic and duration of treatment (mean $\pm \mathrm{SD})$. Different superscript letters indicate significant differences among treatments $(\mathrm{P}<0.05)$.

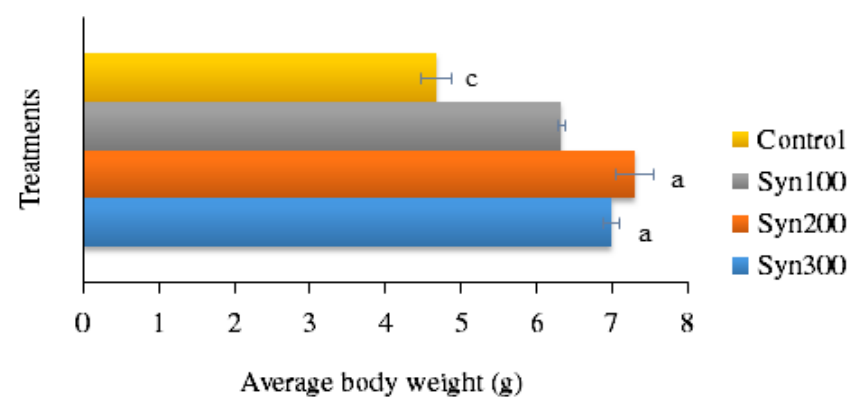

Figure 4. Average body weight of crayfish Cherax quadricarinatus after being fed synbiotic-enriched feed with different level of synbiotic and time duration $($ mean \pm SD). Different superscript letters indicate significant differences among treatments $(\mathrm{P}<0.05)$. 


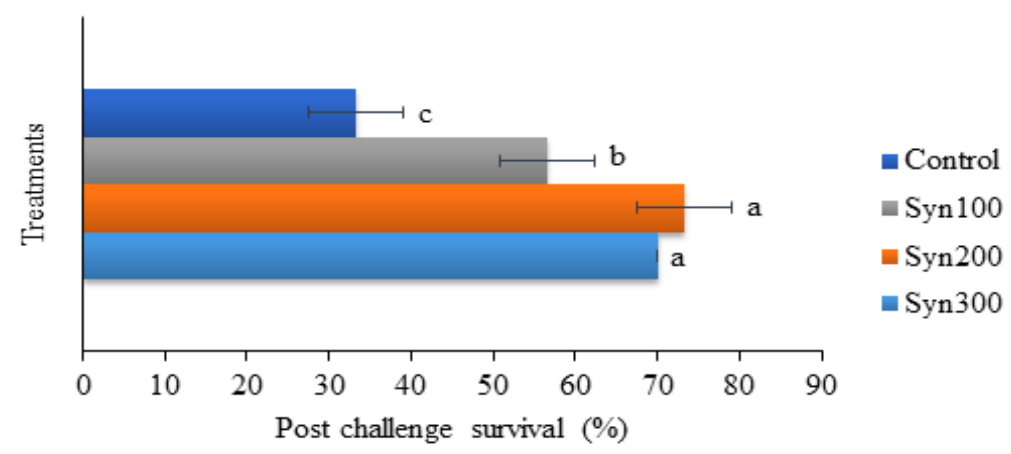

Figure 5. Average percent survival of crayfish Cherax quadricarinatus fed synbiotic-enriched feed (the probiotic Micrococcus spp. and the prebiotic alginate) for 40 days after the challenge test with the bacteria Aeromonas hydrophila $($ mean $\pm \mathrm{SD})$. Different letters indicate significant differences among treatments $(\mathrm{P}<0.05)$.

of the treatment duration showed that the more synbiotics gave, the higher total hemocyte of the crayfish which was observed at day 40 . It showed higher the total hemocytes and significantly different from the treatment duration (Figure 1).

\section{Differential hemocyte count}

It was discovered that the mean percentage of hyaline, semi-granular, and granular of crayfish C. quadricarinatus were change respectively after synbiotic administration of various level and duration of symbiotic, as illustrated in Figures 2 , Table 1 and 2 . The percentage of hyaline and semi-granular of crayfish went down and otherwise, an increased in granular cells after application of synbiotic. The decrease of hyaline and semi-granular cells was only in the form of non-numbered percentages, which seen with an increase in total hemolymph. The decline of hyaline and semi-granular cells was due to a large increase in the percentage of granular crayfish cells.

The mean percentage of hyaline for 40 days fed with Syn 100 (34.7\%) and control (35.1\%) showed greater increased $(\mathrm{P}<0.05)$ than those of the other treatments. The main effect of the treatment duration of synbiotic on crayfish showed that treatment duration of 10 days $(40.63 \%)$ was better than those reared for 40 days $(32.25 \%), 20$ days $(31.25 \%)$ and 30 days (30.50\%). No interaction between synbiotics concentration and duration of treatment.

Statistically, the semi granulocyte cell parameter showed that there was a difference between level of synbiotic and treatment time. In addition, there was an interaction between the level of synbiotic and the length of administration $(\mathrm{P}<0.05)$. The main effects of different synbiotics on the semi-granulocyte response, in general, the treatment of Syn200 and Syn300 were higher than the Syn100 and control on day 10 .
Meanwhile, the administration of Syn100 and control for 20-40 days increased significantly the semi-granular of crayfish.

In the granulocyte parameter, the synbiotic application was also different based on synbiotic concentration and duration of administration $(\mathrm{P}<0.05)$. Both treatments showed interaction with granulocyte crayfish $(\mathrm{P}<0.05)$. The highest granulocytes $(\mathrm{P}<0.05)$ occurred on day $20-40$ with Syn200 and Syn300 applications.

\section{Phagocytic activity}

The mean phagocytic activity for the different level of synbiotic and time duration of crayfish is shown in Figure 3. The crayfish phagocytic activity began to increase on day 10 and was highest $(\mathrm{P}<0.05)$ between day 30 and 40 . In general, the average hemocyte activity of crayfish for 40 days in crayfish fed synbiotic-enriched feed Syn300 and Syn 200 (42.5\% and $40.85 \%$, respectively) was higher than that of crayfish which did not feed with synbiotics $(\mathrm{P}<0.05)$. The duration of 30 days (44.56\%) and 40 days (40.85\%) of the synbiotics administration increased phagocytic activity compared to 20 days $(39.81 \%)$ and 10 days $(28.68 \%)$ of treatment. There was no interaction between the level of the synbiotics and the treatment duration on phagocytic activity.

\section{Body weight}

The administration of synbiotics leads to a higher body weight of crayfish (Fig. 4) than in crayfish fed synbiotic-standard diet $(\mathrm{P}<0.05)$. After being fed synbiotic-enriched feed for 40 days, the body weight of the crayfish fed the synbiotics Syn300 and Syn200 (6.99 \pm 0.11 g; $7.30 \pm 0.25 \mathrm{~g}$, respectively) were heavier than the crayfish fed the synbiotics Syn100 (6.33 \pm 0.04 $\mathrm{g}$ ), and the lowest body weight was control (4.67 $\pm 0.20 \mathrm{~g})(\mathrm{P}<0.05)$. 


\section{Survival rate}

The survival rate of the crayfish reared for 40 days by experimental feed and then tested for the challenge with $A$. hydrophila can be seen in Figure 5. The administration of synbiotics in the treatment of Syn300 and Syn200 indicated mortality (respectively with SR $70.00 \pm 0.00 \%$; $73.33 \pm 5.77 \%$ ) which was significantly higher $(\mathrm{P}<0.05)$ compared to Syn100 $(56.67 \pm 3.33 \%)$ of crayfish, and the lowest was obtained in control $(33.33 \pm 3.33 \%)$.

\section{Discussions}

The results of this study demonstrated that the synbiotics applied through feed could induce nonspecific immune responses and increase body weight of crayfish. Furthermore, due to the crayfish' immune responses increased after the administration of the synbiotics, they could protect the crayfish from $A$. hydrophila infection in the challenge test. This was proven by the higher survival rate in the crayfish fed synbiotics after the challenge test compared to the crayfish without any synbiotics. This present finding also suggests that probiotic and prebiotic are synergistic combination obtained from one of supplement nutrient. Thus, this synergistic combination can be alternative preventive measures and control of bacterial disease in fish farming (Sewaka et al., 2019).

The total hemocyte in crayfish fed synbioticenriched feed containing the prebiotic alginate was higher than the control (Fig.1). This was also seen in the percentage of granulocytes and hemocyte activity which increased and were higher in crayfish fed synbiotic-enriched feed $(\mathrm{P}<0.05)$ compared to those not fed synbiotics. In general, all the immunological experiment parameters increased significantly after the administration of synbiotic-enriched feed. The opposite was observed in the negative control which was fed synbiotic-free feed. The results demonstrated that probiotics presented in the form of synbiotics could increase immune responses, especially nonspecific responses (Azimirad et al., 2016; Wang et al., 2017). Administration of the synbiotic for 40 days could increase the crayfish' body weight more than the control. The probiotic bacteria balanced the micro-flora in the lobsters' digestive tract, improved the absorption of nutrients and as a result improved the nutritional value of the feed. This phenomenon was not seen in crayfish not fed synbiotics. This study is in line with Sewaka et al. (2019) who studied the JA + LGG synbiotic supplementation in tilapia. Due to the development of the intestinal villi is better than the treatment without synbiotics, synbiotics can expand the nutrient absorption areas and more effective. The number of microvilli widens the absorption area and the food can be circulated by the blood throughout the body. Therefore, good quality food is able to meet the energy requirement for maintenance and energy reserves for growth.

Probiotic bacteria hold an important role in the digestive tract. These bacteria thrived in the digestive tract and produce inhibitor compounds which could suppress the growth of harmful bacteria (Fjellheim et al., 2007) and produce digestive enzymes which could aid the digestion process (Gatesoupe, 1999; Shang et al., 2018). Therefore, the proteins and energy from the feed could be utilized more efficiently by the crayfish. As a result, the administration of synbiotics leads to better growth performance. In less than ideal nutritional conditions, but having a high probiotic bacteria population in the digestive tract, the probiotic bacteria could improve the host's survival rate because they are able to increase feed digestibility and provide digestive enzymes or vitamins (Dillon \& Dillon, 2004; Ring $\varnothing$ \& Song, 2016; Elshopakey et al., 2018).

The probiotic bacteria which found in the gut effectively maximized its own energy harvested from these glycans (Flint et al., 2008). This process formed an integrated metabolic network in the gut, and eventually, SCFAs and secondary metabolites that produced during the fermentation process were beneficial to the intestinal ecology and host physiology. In addition to the use of probiotics, the role of prebiotics also begins to be studied. For instance, the role prebiotic in fructooligosaccharide on post-larvae giant freshwater prawn Macrobrachium rosenbergii (Chen et al., 2017). Li et al. (2018) reported the use of inulin and MOS combination in white shrimp, and Elshopakey et al. (2018) use $\beta$-1,4mannobiose on kuruma shrimp (Marsupenaeus japonicus). All the results showed positive effects on growth and immune response. However, most of the tested prebiotic is a commercial product, whereas the natural raw material from marine is not often found (Wang et al., 2016).

Alginate is a major structural polysaccharide of brown algae, which has physicochemical properties beneficial to intestinal ecology (Holdt \& Kraan, 2011). The polysaccharide generates a beneficial bioactive compound with a variety of chemical structure based on alga species 
(Wijesekara et al., 2011). Furthermore, it is easily fermented by certain bacteria in the gut. This fermentation resulted in short-chain fatty acids acts (SCFA) as an important source of energy for epithelial and immune cells.

Alginate contains high nutritional value, various bioactive compounds, and minerals (Cabrita et al., 2016). As prebiotic, alginate is an indigestible food ingredient which beneficial for parasite organism activity, leading to increasing growth and nonspecific immune responses (Poongodi et al., 2012; El-Desouky et al., 2012; Peso-Echarri et al., 2012; Schleder et al., 2017), increasing lipid metabolism (Güroy et al., 2011), viruses resistance and resistance (Boonsri et al., 2017), increasing intestinal effectiveness (Michiels et al., 2012), and increasing the resistance of organisms to stress (Nath et a.l, 2012). In addition, alginate also potentially increases the abundance of bacteriides capillosus bacteria in the gut (Kuda et al., 2017) and has antiviral, antifungal and antibacterial activity (Niu et al., 2015).

Study on several marine algae species have been conducted in aquaculture including Undaria pinnatifida (Schleder et al., 2017), Sargassum philippendula (Pallaoro et al., 2016), Ulva lactuca and Gracilaria parvispora (RodríquezGonzález et al., 2014), Hypnea cervicornis, and Cryptoremia crenulata (Silva \& Barbosa, 2009). The results of those studies are in line with the utilization of natural ingredients and natural antibiotic which is environmentally friendly. Various studies have also been documented related to the use of prebiotic and probiotic bacteria. It showed good results on growth and immune response. However, if probiotic and prebiotic bacteria are applied together in the form of synbiotics, it will produce advanced results compared to the provision of prebiotics as a single compound (Safari et al., 2017).

The application of synbiotic with different level of prebiotic resulted in dissimilar growth performance and immune responses in the lobsters. The application of the prebiotics at concentrations of 200 and $300 \mathrm{mg} / \mathrm{L}$ (Syn300 and Syn200) in general could improve the crayfish' growth performance, immune responses, and survival rate compared to those lower concentration of prebiotics $(100 \mathrm{mg} / \mathrm{L}$ or Syn 100$)$. These results demonstrated that $200 \mathrm{mg} / \mathrm{L}$ and $300 \mathrm{mg} / \mathrm{L}$ of alginate were the optimum concentration to boost growth performance, immune responses, and survival rate in crayfish, whereas administration of $100 \mathrm{mg} / \mathrm{L}$ synbiotic was inadequate. According to the treatment duration of synbiotics, it could be given during the rearing periods. This was based on data from the synbiotics administration which showed a higher difference on day 30 and 40 than other time treatments on all test parameter.

The survival rate of lobsters after 40 days of being fed using synbiotic-enriched feed then challenged with a virulent strain of A. hydrophila was higher than that of the crayfish fed the nonsynbiotic-enriched feed. The results of this study demonstrated that the probiotic bacteria Micrococcus spp. could indeed induce the lobsters' immune response. Sufficient amounts of the prebiotics fucoidan and alginate supported the existence of probiotic bacteria in the crayfish's digestion tract, which in turn induced immune responses strong enough to protect the crayfish against infections of $A$. hydrophila.

The total hemocyte, an immune response parameter, could affect the crayfish's ability to react to unfamiliar matter and various responses to infection (Johansson et al., 2000); therefore, the increased total hemocyte resulted in improved health in the lobster. Hemocytes play a role in the process of phagocytosis, encapsulation, degradation, and nodular aggregation of pathogens and foreign bodies. This total hemocyte indicated the ability of the crayfish to defend itself against pathogens. In crustacean, the Increase of hemocyte level indicates resistance in the body which attempts to remove the pathogens that infected the body through phagocytosis. In the present study, synbiotic alginate and Micrococcus spp can stimulate an increase in THC level. The optimal THC level can be gained at 200 and $300 \mathrm{mg} / \mathrm{L}$. This study is in line with Partida-aragure et al. (2013) with the administration of inulin in white shrimp.

In the present study, the differential hemocyte parameters increased. The increased differential hemocyte is an indication of the crayfish's elevated health status or improved resistance. Hyaline cells which have an active role in phagocytosis and encapsulation and proPO, cytotoxic, granulocytes, which accumulated in connective tissue, were easily released into the hemolymph to perform proPO and cytotoxic functions (Johansson \& Soderhall, 1989). The increase of granulocyte crayfish cells after the application of alginate prebiotics and probiotic bacteria Micrococcus sp. had an effect on the increase of phagocytic activity. Granulocytes are 
important phagocytic cells in crayfish in order to conduct phagocytosis of foreign particles. After being challenged with $A$. hydrophila, the crayfish fed synbiotic-enriched feed had significantly higher survival rates $(\mathrm{P}<0.05)$. This demonstrated the fact that non-specific immune responses performed defence mechanisms which were activated by the probiotic bacteria, making the crayfish more resistant to pathogenic bacteria.

The use of seaweed as a beneficial nutrient has been widely developed for human needs because it acts as an antimicrobial compound (Pina-Perez et al., 2017), cancer prevention, blood pressure reduction, and antioxidants (Qin, 2018). Furthermore, the use of alginate from seaweed as synbiotic on tilapia (O. niloticus) has been studied by Van Doan et al. (2017) using alginate and probiotic bacteria Lactobacillus plantarum. The results showed that this synbiotic potentially increased innate immune response, disease resistance, and growth performance. The application of alginate as prebiotic has also been studied by Kuda et al. (2015) against Salmonella typhimurium, Listeria monocytogenes, and Vibrio parahaemolyticus infections in mice. This alginate administration increases transepithelial resistance from HT-29-Luc monolayer cells and decreases the number of pathogens in the liver.

A study on the effects of the administration of probiotics and commercial prebiotic on growth has been documented by Talpur et al. (2014). The results of the study demonstrated that the administration of L. acidophilus, yeast, and $B$-glucan could significantly increase body weight, protein efficiency ratio (PER), and feed conversion ratio (FCR) in fish. The administration of the prebiotic fructooligosaccharide (FOS) could also improve immune responses, stress resistance, digestive activities, and growth in the larvae of Caspian roach fish (Soleimani et al., 2012). The probiotics in synbiotics increase the secretion of alginate lyase enzymes, amylase, and proteases (Zokaeifar et al., 2012). Synbiotic can also regulate the balance of intestinal microbes lead to accelerating digestion and absorption of feed (Gomez \& Balcazar, 2008).

This is also in line with Shang et al. (2018) who stated that intestinal microbiota plays an important role in health, nutrition, metabolic, and immune homeostasis of the host. As symbiotic bacteria, these microorganisms strongly rely on fiber and polysaccharides that cannot be digested as an energy source. Polysaccharides reach the gut are fermented by intestinal microbiota lead to a fundamental impact on the intestinal ecology. Therefore, alginates from Sargassum sp. brown algae and Micrococcus spp bacteria are important as synbiotics for fish cultivation, especially freshwater crayfish.

\section{CONCLUSION}

The synbiotics potentially induced immune responses, improve body weight, and the resistance to the pathogenic bacteria A. hydrophila in crayfish; the best concentration for the prebiotic was at $200 \mathrm{mg} / \mathrm{L}$ and for the probiotic bacteria Micrococcus spp. at a density of $10^{5}$ cells $/ \mathrm{mL}$.

\section{REFERENCES}

Ammar HH, Lajili S, Sakly N, Cherif D, Rihouey C, Le Cerf D, Bouraoui A, Majdoub H. 2018. Influence of the uronic acid composition on the gastroprotective activity of alginates from three different genus of Tunisian brown algae. Food Chemistry 239 : 165-171.

Amrullah, Sukenda, Harris E, Alimuddin, Lusiastuti AM. 2014a. The Immunoprotection of toxoid protein vaccine from Streptococcus agalactiae bacteria in Nile tilapia Oreochromis niloticus [Dissertation]. Bogor: IPB University.

Amrullah, Sukenda, Harris E, Alimuddin, Lusiastuti AM. 2014b. Immunogenicity of the $89 \mathrm{kDa}$ Toxin Protein from extracellular product of Streptococcus in Oreochromis niloticus. Journal of Fisheries and Aquatic Science 9: 176-186.

Amrullah, Wahidah, Yusuf A, Andriani. 2014c. Selection of probiotic bacteria and in vitro evaluation of alginate as a prebiotic for freshwater lobster Cerax quadricarinatus. Pakistan Journal of Nutrition 13: 666-671.

Azimirad M, Meshkini S, Ahmadifard N, Hoseinifar SH. 2016. The effects of feeding with synbiotic (Pediococcus acidilactici and fructooligosaccharide) enriched adult Artemia on skin mucus immune responses, stress resistance, intestinal microbiota and performance of angelfish Pterophyllum scalare. Fish and Shellfish Immunology 54: 516-522.

Blanco-Pascual N, Montero MP, Gómez-Guillén MC. 2014. Antioxidant film development from unrefined extracts of brown seaweeds Laminaria digitata and Ascophyllum nodosum. Food Hydrocolloids 37: 100-110. 
Boonsri N, Rudtanatip T, Withyachumnarnkul B, Wongprasert K. 2017. Protein extract from red seaweed Gracilaria fisheri prevents acute hepatopancreatic necrosis disease (AHPND) infection in shrimp. Journal Application of Phycology 29: 1597-1608.

Cabrita ARJ, Maia MRG, Oliveira HM, SousaPinto I, Almeida AA, Pinto E, Fonseca AJM. 2016. Tracing seaweeds as mineral sources for farm-animals. Journal Application of Phycology 28: 3135-3150.

Cai J. Huang Y, Wei S, Ouyang Z, Huang X, Qin Q. 2013. Characterization of LPS-induced TNF $\alpha$ factor (LITAF) from orange-spotted grouper Epinephelus coioides. Fish and Shellfish Immunology 35: 1858-1866.

Caipang CMA, Lazado CC. 2015. Nutrituional impacts on fish mucosa: immunostimulants, pre-and probiotics. in Beck BH and Peatman E (eds), Mucosal Health in Aquaculture. London: Academic Press, pp. 211-272.

Chang HN, Kim NJ, Kang J, Jeong CM. 2010. Biomass-derived volatile fatty acid platform for fuels and chemicals. Biotechnology Bioprocess Engineering 15: 1-10.

Chen WW, Romano N, Ebrahimi M, Natrah I. 2017. The effects of dietary fructooligosaccharide on growth, intestinal short chain fatty acids level and hepatopancreatic condition of the giant freshwater prawn Macrobrachium rosenbergii post-larvae. Aquaculture 469: 95-101

Dierick N, Ovyn A, De Smet S. 2010. In vitro assessment of the effect of intact marine brown macro-algae Ascophyllum nodosum on the gut flora of piglets. Livestock Science 133: 154-156.

Dillon RJ, Dillon VM. 2004. The gut bacteria of insects: nonpathogenic interactions. Annual Review of Entomology 49: 71-92.

Draget K I, Smidsrod O, Skjak-Braek G. 2005. Alginates from algae, first ed. In: Steinbuchel, A., Rhee, S.K. (Eds.), Polysaccharides and Polyamides in the Food Industry: Properties, Production and Patents, Vol. 1. WileyBlackwell, pp. 1-30.

El-Desouky H, El-Asely AA, Shaheen A, Abbass A. 2012. Effects of Zingiber officinalis and Cyanodon dactylon on the growth performance and immune parameters of Macrobrachium rosenbergii. World Journal of Fish and Marine Sciences 4: 301-307.

Elshopakey GE, Risha EF, Abdalla OA, Okamura Y, Hanh VD, Ibuki M, Sudhakaran R, Itami T.
2018. Enhancement of immune response and resistance against Vibrio parahaemolyticus in kuruma shrimp Marsupenaeus japonicus by dietary supplementation of $\beta$-1,4-mannobiose. Fish and Shellfish Immunology 74: 26-34.

Fjellheim AJ, Playfoot KY, Skjermo J, Vadstein O. 2007. Vibrionaceae dominates the microflora antagonistic towards Listonella anguillarum in the intestine of cultured Atlantic cod Gadus morhua L. larvae. Aquaculture 269: 98-106.

Flint HT, Bayer EA, Rincon MT, Lamed R, White BA. 2008. Natural Review Microbiology 6: 121-131.

Gatesoupe FJ. 1999. The use of probiotics in aquaculture. Aquaculture 180:147-165.

Gomez GD, Balcázar JL. 2008. A review on the inter-actions between gut microbiota and innate immunity of fish. FEMS Immunology \& Medical Microbiology 52: 145-154

Güroy D, Güroy B, Merrifield DL, Ergün S, Tekinay AA, Yiğit M. 2011. Effect of dietary Ulva and Spirulina on weight loss and body composition of rainbow trout, Oncorhynchus mykiss (Walbaum), during a starvation period. Journal of Animal Physiology Animal Nutrition 95: 320-327.

Hindu SV, Thanigaivel S, Vijayakumar S, Chandrasekaran N, Mukherjee A, Thomas J. 2018. Effect of microencapsulated probiotic Bacillus vireti 01-polysaccharide extract of Gracilaria folifera with alginatechitosan on immunity, antioxidant activity and disease resistance of Macrobrachium rosenbergii against Aeromonas hydrophila infection. Fish and Shellfish Immunology 73: 112-120.

Holdt SL, Kraan S. 2011. Bioactive compounds in seaweed: functional food applications and legislation. Journal of Applied Phycology 915: 543-597.

Ibrahem MD, Fathi M, Mesalhy S, Abd El-Aty AM. 2010. Effect of dietary supplementation of inulin and vitamin $\mathrm{C}$ on the growth, hematology, innate immunity, and resistance of Nile tilapia Oreochromis niloticus. Fish and Shellfish Immunology 29: 241-246.

Johansson MW, Keyser P, Sritunyalucksana K, Soderhall K. 2000. Crustacean haemocytes and haematopoiesis. Aquaculture 191: 45-52.

Johansson MW, Soderhall K. 1989. Cellular immunity in crustaceas and the proPO system. Parasitology Today 5: 171-176.

Jung KA, Lim SR, Kim Y, Park JM. 2013. 
Potentials of macroalgae as feedstocks for biorefinery. Bioresources Technology 135: 182-190.

Kuda T, Kosaka M, Hirano S, Kawahara M, Sato M, Kaneshima T, Nishizawa M, Takahashi H, Kimura B. 2015. Effect of sodium-alginate and laminaran on Salmonella typhimurium infection in human enterocyte-like HT-29Luc cells and BALB/c mice. Carbohydrate Polymers 125: 113-119.

Kuda T, Hirano S, Yokota Y, Eda M, Takahashi H, Kimura B. 2017. Effect of depolymerized sodium alginate on Salmonella typhimurium infection in human enterocyte-like HT-29-Luc cells and BALB/c mice. Journal of Functional Foods 28: 122-126.

Li Y, Liu H, Dai X, Li J, Ding F. 2018. Effects of dietary inulin and mannan oligosaccharide on immune related genes expression and disease resistance of Pacific white shrimp Litopenaeus vannamei. Fish and Shellfish Immunology 76: 78-92.

Liu Y, Gibson GR, Walton EG. 2017. A threestage continuous culture approach to study the impact of probiotics, prebiotics and fat intake on faecal microbiota relevant to an over $60 \mathrm{~s}$ population. Journal of Functional Foods 32: 238-247.

Michiels J, Skrivanova E, Missotten J, Ovyn A, Mrazek J, Smet SD. 2012. Intact brown seaweed Ascophyllum nodosum in diets of weaned piglets: effects on performance, gut bacteria and morphology and plasma oxidative status. Journal of Animal Physiology Animal Nutrition 96: 1101-1111.

Montero J, Gomez-Casado E, Garcia-Alcazar A, Meseuer J, Mulero V. 2014. Flagellin from Marinobacter algicola and Vibrio vulnificus activates the innate immune response of gilthead seabream. Developmental and Comparative Immunology 47: 160-167.

Munir MB, Hashim R, Chai YH, Marsh TL, Nor SAM. 2016. Dietary pretbiotics and probiotics influence growth performance, nutrient digestibility and the expression of immune regulatory genes in snakehead Channa striata fingerlings. Aquaculture 460: 59-68.

Murdinah, Amini S, Irianto HE, Darmawan M, Subaryono, Sinurat E. 2005. Laporan teknis riset optimasi pemanfaatan makro dan microalgae. Jakarta: Bagian Proyek Riset Pengolahan Produk dan Sosialisasi Ekonomi Kelautan dan Perikanan.
Nath PR, Khozin-Goldberg I, Cohen Z, Boussiba S, Zilberg D. 2012. Dietary supplementation with the microalgae Parietochloris incisa, increases survival and stress resistance in guppy Poecilia reticulata fry. Aquaculture Nutrition 18: 167-180.

Niu J, Chen X, Lu X, Jiang SG, Lin HZ, Liu YJ, Tian LX. 2015. Effects of different levels of dietary wakame Undaria pinnatifida on growth, immunity and intestinal structure of juvenile Penaeus monodon. Aquaculture 435: 78-85.

Pallaoro MF, do Nascimento Vieira F, Hayashi L. 2016. Ulva lactuca (chlorophyta ulvales) as co-feed for Pacific white shrimp. Journal Applied of Phycology 28: 3659-3665

Park Y, Moniruzzaman M, Lee S, Hong J, Won S, Lee JM, Yun H, Kim KW, Ko D, Bai SC. 2016. Comparison of the effects of dietary single and multi-probiotics on growth, nonspecific immune responses and disease resistance in starry flounder Platichthys stellatus. Fish and Shellfish Immunology 59: 351-357.

Partida-arangure BO, Luna-gonzalez A, Fierrocoronado JA, Flores-miranda, MDC, Gonzalezocampo. 2013. Effect of inulin and probiotic bacteria on growth survival, immune response and prevalence of white spot syndrome virus (WSSV) in Litopenaeus vannamei cultured under laboratory conditions. African Journal of Biotechnology 12: 3366-3375

Pasnik DJ, Evans JJ, Panangala VS, Kleus PH, Shelby RA, Shoemaker CA. 2005. Antigenicity of Streptococcus agalactiae extracellular products and vaccine efficacy. Journal of Fish Diseases 28: 205-212.

Peso-Echarri P, Frontela-Saseta C, SantaellaPascual M, García-Alcázar A, Abdel I, Ros-Berruezo G, Martínez-Graciá C. 2012. Sodium alginate as feed additive in cultured sea bream Sparus aurata: Does it modify the quality of the flesh? Food Chemistry 135: 699-705

Pina-Perez MC, Rivas A, Martinez A, Rodrigo D. 2017. Review. Antimicrobial potential of macro and microalgae against pathogenic and spoilage microorganisms in food. Food Chemistry 235: 34-44.

Poongodi, R, Saravanabhavan P, Muralisankar T, Radhakrishnan S. 2012. Growth promoting potential of garlic, ginger, turmeric and fenugreek on the freshwater prawn 
Macrobrachium rosenbergii. International Journal of Pharma and Bio Sciences 3: 914 926.

Qin Y. 2018. Bioactive Seaweeds for Food Applications. Natural Ingredients for. Healthy Diets. London: Elsevier Inc. Academic Press.

Ring $\varnothing$ E, Song SK. 2016. Application of dietary supplements (synbiotics and probiotics in combination with plant products and $\beta$-glucans) in aquaculture. Aquaculture Nutrition 22: 4-24.

Rodríguez-González $\mathrm{H}, \quad$ Orduña-Rojas $\mathrm{J}$, Villalobos-Medina JP, García Ulloa M, Polanco-Torres A, López-Álvarez ES, Montoya-Mejía M, Hernández-Llamas A, 2014. Partial inclusion of Ulva lactuca and Gracilaria parvispora meal in balanced diets for white leg shrimp Litopenaeus vannamei. Journal Applied of Phycology 26: 2453-2459.

Safari O, Paolucci M. 2017. Modulation of growth performance, immunity, and disease resistance in narrow-clawed crayfish Astacus leptodactylus leptodactylus (Eschscholtz, 1823) upon synbiotic feeding. Aquaculture 479: 333-341.

Schleder DD, da Rosa JR, Guimarães AM, Ramlov F, Maraschin M, Seiffert WQ, do Nascimento Vieira F, Hayashi L, Andreatta ER. 2017. Brown seaweeds as feed additive for white-leg shrimp: effects on thermal stress resistance, midgut microbiology, and immunology. Journal Applied of Phycology 29: 2471-2477.

Seon J, Lee T, Lee SC, Pham HD, Woo HD, Woo HC, Song M. 2014. Bacterial community structure in maximum volatile fatty acids production from alginate in acidogenesis. Bioresource Technology 157: 22-27.

Sewaka M, Trullas C, Chotiko A, Rodkhum C, Chansue N, Boonanuntanasarn S, Pirarat N. 2019. Efficacy of synbiotic Jerusalem artichoke and Lactobacillus rhamnosus GGsupplemented diets on growth performance, serum biochemical parameters, intestinal morphology, immune parameters and protection against Aeromonas veronii in juvenile red tilapia Oreochromis spp. Fish and Shellfish Immunology 86: 260-268.

Shang Q, Jiang H, Caia C, Haoa J, Lia G, Yua G. 2018. Gut microbiota fermentation of marine polysaccharides and its effects on intestinal ecology: an overview. Carbohydrate Polymers 179: 173-178.

Sharifuzzaman SM, Al-Harbi AH, Austin B.
2014. Characteristics of growth, digestive system functionality, and stress factors of rainbow trout fed probiotics Kocuria SM1 and Rhodococcus SM2. Aquaculture 418-419: 55-61.

Silva RL, Barbosa JM. 2009. Seaweed meal as a protein source for the white shrimp Litopenaeus vannamei. Journal Applied Phycology 21: 193-197

Soleimani N, Hoseinifar SH, Merrifield DL, Barati M, Abadi ZH. 2012. Dietary supplementation of fructooligosaccharide (FOS) improves the innate immune response, stress resistance, digestive enzyme activities and growth performance of Caspian roach Rutilus rutilus fry. Fish and Shellfish Immunology 32: 316321.

Song M, Xie J, Peng X, Li H. 2013. Identification of protective immunogens from extracellular secretome of Edwardsiella tarda. Fish and Shellfish Immunology 35: 1932-1936

Speranza B, Racioppo A, Beneduce L, Bevilacqua A, Sinigaglia M, Corbo MR. 2017. Autochthonous lactic acid bacteria with probiotic aptitudes as starter cultures for fish-based products. Food Microbiology 65: 244-253.

Talpur AD, Munir MB, Mary A, Hashim R. 2014. Dietary probiotics and prebiotics improved food acceptability, growth performance, haematology and immunological parameters and disease resistance against Aeromonas hydrophila in snakehead Channa striata fingerlings. Aquaculture 426-427: 14-20.

Torrecillas S, Makoi A, Cabaliero MJ, Montero D, Robaina L, Tort L. 2007. Immune stimulations and improved infection resistance in European sea bass Dicentrarchus labrax fed mannan oligosaccharides. Fish and Shellfish Immunology 23: 969-981

Van Doan H, Hoseinifar SH, Tapingkae W, Tongsiri S, Khamtavee P. 2016. Combined administration of low molecular weight sodium alginate boosted immunomodulatory, disease resistance and growth enhancing effects of Lactobacillus plantarum in Nile tilapia Oreochromis niloticus. Fish and Shellfish Immunology 58: 678-685.

Wang XT, Wang LL, Li SY, Li XY, Xu YP. 2016. The mechanisms of action of synbiotic and its application in aquaculture. Feed research 12: 6-14 [In Chinese, with English abstract]

Wang X, Yong S, Wang L, Li X, Qu K, Xu Y. 2017. Synbiotic dietary supplement affects 
growth, immune responses and intestinal microbiota of Apostichopus japonicus. Fish and Shellfish Immunology 68: 232-242.

Wijesekara I, Pangestu R, Kim SK. 2011. Biological activities and potential health benefits of sulfated polysaccharides derived from marine algae. Carbohydrate polymers 84: 14-21.

Zhou QC, Buentello JA, Gatlin III DM. 2010. Effects of dietary prebiotics on growth performance, immune response and intestinal morphology of red drum Sciaenops ocellatus. Aquaculture 309: 253-257.

Zokaeifar H, Balcázar JL, Saad CR, Kamarudin MS, Sijam K, Arshad A. 2012. Effects of Bacillus subtilis on the growth performance, digestive enzymes, immune gene expression and disease resistance of white shrimp, Litopenaeus vannamei. Fish and Shellfish Immunology 33: 683-689. 